\title{
Testicular arteries systematization based on different levels of scrotal configuration in caprines
}

\author{
Sistematização da artéria testicular em caprinos segundo a configuração escrotal
}

\author{
Mônica Marco de Almeida ${ }^{\mathrm{I}}$ Antônio Chaves de Assis Neto ${ }^{\mathrm{II}}$ Alexandra Klindline Penno ${ }^{\mathrm{I}}$ \\ Airton Mendes Conde Júnior ${ }^{\mathrm{I}}$ Danilo Jose Ayres de Menezes ${ }^{\mathrm{III}}$ Gabriel Ribas Pereira ${ }^{\mathrm{IV}}$ \\ Laurita Martins de Azevêdo ${ }^{I}$ Maria Acelina Martins de Carvalho ${ }^{I}$
}

\begin{abstract}
The objective of this study was to describe the distribution of testicular arterial vessels in caprines with different degrees of scrotal division. Scrotal configurations were classified as follows; Group I: scrotum without bipartition; Group II: scrotum showing a ventral division until the middle of the testis; and, Group III: scrotal separation extended beyond the middle of the testis. A colored vinyl acetate solution was injected into 60 testicular arteries (30 pairs). After, the samples were submitted to corrosion cast method to obtain tubular vascular models for macroscopic analysis. We observed that the testicular arteries emerge from the abdominal aorta, cross the inguinal canal to become coiled and involved by the pampiniform plexus. Close to the caudal extremity of the testis, the arteries become divided in cranial and caudal branches that emit collateral vessels to originate emerging branches. Testicles with intermediate level of scrotal division (group II) showed a smaller amount of those branches than the others, being the most populated the ventrolateral and the dorsolateral quadrants. The origin, distribution and localization of the testicular arteries did not show any differences related to the degree of scrotal division in caprines.
\end{abstract}

Key words: testicles, testicular arteries, scrotal configuration, caprines.

\section{RESUMO}

O objetivo deste trabalho foi analisar a distribuição dos vasos arteriais nos testículos em caprinos com diferentes graus de divisão escrotal. A configuração escrotal foi classificada da seguinte forma: Grupo I: constituído por caprinos com escroto único, Grupo II: com escroto separado até a metade do testículo e Grupo III: com separação escrotal estendendo-se além da metade do testículos. As artérias foram injetadas e coradas com solução de acetado de vinil, sendo os orgãos (30 pares) submetidos à corrossão para obtenção dos moldes vasculares. As artérias testiculares emergem da aorta abdominal, com trajeto retilíneo, atravessam o canal inguinal, apresentam-se espiraladas e envolvidas parcialmente pelo plexo pampiniforme. Próximo à extremidade caudada do testículo, dividem-se mais freqüentemente nos ramos cranial $e$ caudal, os quais emitem vasos colaterais, de onde emergem ramos penetrantes. Os testículos dos animais com nível intermediário de divisão escrotal (Grupo II) apresentam menor quantidade destes ramos, sendo os quadrantes mais povoados o ventrolateral e o dorsolateral. Conclui-se que a origem, o trajeto e a distribuição das artérias testiculares não apresentam variações relacionadas ao grau de divisão escrotal em caprinos.

Palavras-chave: testículos, artérias articulares, configuração escrotal, caprinos.

\section{INTRODUCTION}

Caprines live harmoniously in adverse environmental of the tropical regions, showing efficient mechanisms of self-adaptation. The angioarchitecture of the testicle plays an important role in the thermoregulation of this organ in many species, such as in bovine (HESS et al., 1990) and ovine (PASCUALY \& ELOY, 1985).

In native caprines that have been born in Brazilian Northeast region, it was reported to have a two-compartment scrotum division, conferring to them

IDepartamento Morfologia Veterinária, Centro de Ciências Agrárias, Universidade Federal do Piauí (UFPI), Bairro Ininga, Teresina, PI, Brasil.

IUnidade Experimental de Dracena, Universidade Estadual Paulista “Júlio de Mesquita Filho”, Rod. Cmte. João Ribeiro de Barros, 294, km 651, 17900-000, Dracena, SP, Brasil. E-mail: antonioassis@dracena.unesp.br. Autor para correspondência.

IIIUnidade Academica de Medicina Veterinária, Universidade Federal de Campina Grande (UFCG), 58700-970, Patos, PR, Brasil.

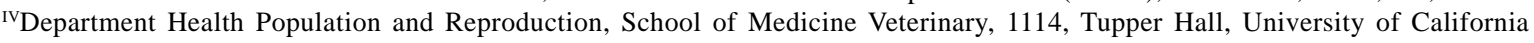
Davis, 95616, CA, USA. 
a greater volume and number of ejaculated spermatozoa when compared to caprines that possess an entire scrotum (PASCUALY \& ELOY, 1985)

It is not well understood the correlation between bipartition in the scrotum in caprines and testicular thermoregulation. In the literature, mainly concerning ovine species, descriptions about the vascular arrangement of the spermatic funiculus have been observed (NOORDHUIZEN-STASSEN et al., 1985; CARVALHAL et al., 2000) and little attention has been given to caprine species (SOUZA et al., 1992; OLIVEIRA et al., 2002). No report was found on vascular configuration in caprines testicles with scrotal bipartition.

The objective of the present study was to analyze the origin and the distribution of the arterial vessels in caprines testicles with different degrees of scrotal division.

\section{MATERIALS AND METHODS}

This research was conducted at the Centre of Agrarian Science at the Federal University of Piauí, Brazil. Thirty native caprines without defined breed, from 8 to 24 months of age, from the Brazilian state of Piauí were used in this study.

Three groups of ten animals each were classified according to the scrotal configuration as follows: scrotum without bipartition (group I); scrotum showing a ventral division until the middle of the testis (group II); and, scrotal separation extended beyond the middle of the testis (group III).

Testicles were removed from abdominal cavity to evaluate the origin and the distribution of the testicular arteries. After dissection, vessels were canulated with 20-gauge needle and vascular system was washed with saline solution $0.9 \%$. Samples were injected with $3 \mathrm{~mL}$ of acetone in each artery followed by an injection with $3 \mathrm{~mL}$ solution of vinyl acetate (VMCH-B:1099 - Union Carbide Corporation, Chemical and Plastic) colored with a nitrocellulose red-molibdate lacquer dye (Glassurite do Brazil S.A. - Paint Industry Brazil). Samples were washed in running water for a period of three hours, immersed in 30\% sulfuric acid solution for 72- to 96-hour period, and then washed with distilled water. This technique allowed us to maintain vessels vascular structure.

Corrosion cast were used to evaluate morphology of testicular artery and the number of cranial, caudal and penetrating branches. The distributions of the vessels in the dorsomedial (DM), ventromedial (VM), dorsolateral (DL) and ventrolateral (VL) quadrants were achieved through an imaginary trace of two planes perpendicular among themselves. A long axis longitudinally to each testis was used to delimit the lateral and medial halves, and other axes horizontally to the testis were used to delimit the dorsal and ventral half. Images were captured using a Nikon digital photographic camera.

Numeric values were submitted to analysis of variance and their means compared by Duncan's test. Statistical Analysis System (SAS) software was used and P-value was set at 0.05 .

\section{RESULTS}

Origin of the testicular artery

Thirty pairs of caprine testicles were used in this experiment. After abdominal dissection we observed that, in all cases, the origin of the testicular arteries is situated in the ventral surface of the abdominal portion of the aorta. These arteries showed a close relationship to the caudal mesenteric artery and the right testicular artery more cranial (53.3\%), or more caudal (20.0\%) or at the same level (26.7\%) to the left testicular artery.

Testicular arteries showed a rectilinear itinerary in the ventrocaudal direction towards to the vaginal opening and together with veins and ductus deferens as part of the spermatic funiculus. At this point, the arteries are coiled until they reach the cranial extremity of the testis (Figure 1A). In this funicular segment, the testicular artery emits two epididymal branches (Figure 1B), one lateral and another medial, which can be originated from the common (52.2\%) or the independent (47.8\%) trunk.

The epididymis lateral artery is predominantly responsible for the vascularization of the epididymis head, while the medial artery vascularizes the body and the tail of the epididymis. However, in all analyzed testicles the lateral vessels emit branches to the epididymis body and the medial artery vessels emit branches to the epididymis head. The lateral branches arise dorsally to the medial branches of the testicles in $56.25 \%$, ventrally in $12.5 \%$ and at the same level in $31.25 \%$ of the cases studied.

Ramification and distribution of the testicular arteries At the cranial extremity of the testis, the testicular arteries are superficially located throughout the tunica albuginea. The pampiniform plexus represented by a fine network of testicular veins almost completely involves the segment of the testicular artery in the spermatic funiculus. These testicular veins are prolonged to embrace the epididymis arterial branches 


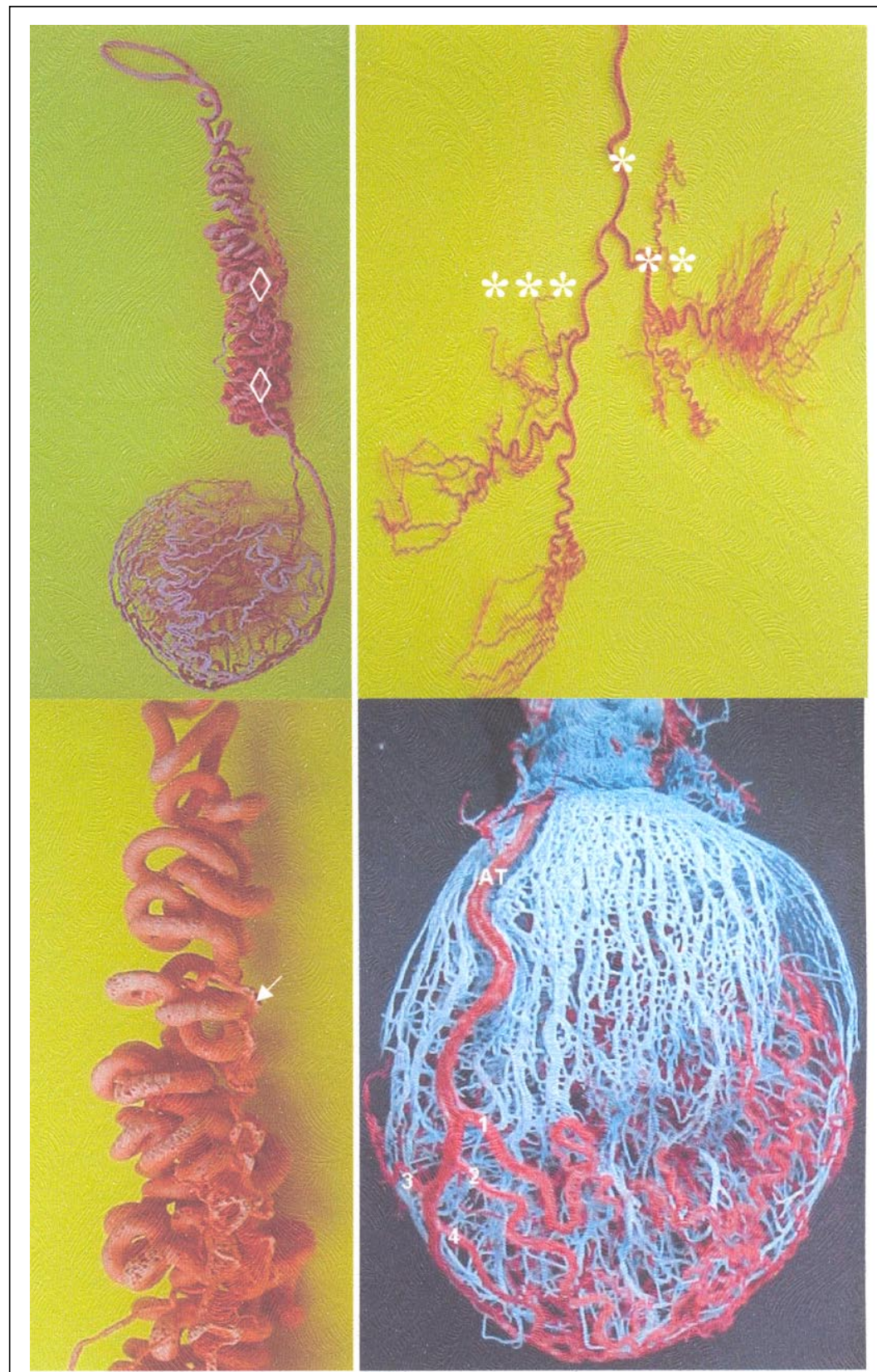

Figure 1 - Arterial vascular cast of caprine testicles: A - Coiled segment in the spermatic funiculus ( $\diamond$ ); B - Origin of the epididymis artery (seta); C - Bifurcation in the cranial $(* *)$ and caudal $(* * *)$ branches; D - The testicular artery (AT) becomes divided into several branches: 1,2 and 4 (caudal) and 3 (cranial).

and to give a conical shape to the funiculus to build part of the cranial extremity of the testis.

Testicular artery reaches the caudal extremity of the testis and becomes divided in cranial and caudal branches in $80 \%$ of the samples (Figure $1 C)$, they will originate a variable number of cranial (1 to 6 ) and caudal branches ( 1 to 4 ) in $20 \%$ of the remaining samples (Figure 1D).
In our study, the cranial and caudal arterial branches did not surround the entire testis. These arterial branches form collateral branches that continue into the parenchyma until reach the testicular mediastinum where they are called penetrating branches. The collateral branches are observed at the caudal branch in $48.8 \%$, at the cranial branch in $39.5 \%$, and at the same level of bifurcation in $11.6 \%$ of the 
cases. The cranial collateral branches supply the cranial region of the testicle (39.5\%) and the caudal collateral branches contribute to the caudal region in $9.3 \%$ of the cases.

The mean values of penetrating branches originated from the cranial and caudal arterial branches are presented in table 1 . The number of total animals classified in Group I showed a tendency to have a larger number of penetrating cranial and caudal branches when compared to animals located in Group II and Group III, although the data could not be statistically confirmed due to the small sampling used in our study.

The means values of penetrating branches according to their distribution in the dorsomedial (DM), dorsolateral (DL), ventromedial (VM) and ventrolateral (VL) quadrants, are shown in table 2. All the animals showed a large amount of the penetrating branches with different degrees of scrotal division in caprine testicles. The total amount of penetrating branches in caprine testicles with different scrotal division levels is shown in table 3.

\section{DISCUSSION}

The origin of the testicular arteries in the ventral surface of the abdominal portion of the aorta, close to the caudal mesenteric artery, is in agreement with GETTY'S (1986) findings in ruminants. In the literature, BARONE (2003) reported that the right testicular artery could be originated from the renal artery in caprines. It was observed that $53.3 \%$ of the paired testis had the right testicular artery more cranial (53.3\%), or more caudal (20.0\%) or at the same level (26.7\%) of the left testicular artery.

The distribution of testicular arteries in caprines were similar to described for bovines (HESS et al., 1990; CARVALHAL et al., 2000) and buffalos (MACHADO et al., 1996). The present study showed that lateral and medial epididymis branches originate from a common or separated trunk, although MACHADO et al., (1996) described as a unique branch in buffalos.

Table 1 - Mean values and respective standard deviations corresponding to the number of penetrating vessels derived from the cranial and caudal branches with defferente degrees of scrotal division in caprines.

\begin{tabular}{lcll}
\hline Branches & Group I & Group II & Group III \\
\hline Cranial & $17 \pm 7.35$ & $9 \pm 3.83$ & $12 \pm 8.42$ \\
Caudal & $19 \pm 2.12$ & $15 \pm 7.78$ & $16 \pm 9.96$ \\
Total & $41 \pm 4.95$ & $31 \pm 7.78$ & $28 \pm 17.66$
\end{tabular}

Statistical analysis using Duncan's test $(\mathrm{P}>0.05)$. Scrotum without bipartition (group I); Scrotum showing a ventral division until the middle of the testis (group II); and Scrotum separation extended beyond the middle of the testis (group III).
Table 2 - Mean and relative standart deviations of the penetrating branches with different degrees of scrotal division in caprines testicles.

\begin{tabular}{llll}
\hline Quadrante & Group I & Group II & Group III \\
\hline DM & $4 \pm 3.23^{\mathrm{b}}$ & $1 \pm 1.43^{\mathrm{c}}$ & $2 \pm 2.40^{\mathrm{b}}$ \\
DL & $11 \pm 4.33^{\mathrm{a}}$ & $6 \pm 2.95^{\mathrm{a}}$ & $10 \pm 6.29^{\mathrm{a}}$ \\
VM & $6 \pm 4.46^{\mathrm{b}}$ & $3 \pm 2.10^{\mathrm{b}}$ & $4 \pm 2.32^{\mathrm{b}}$ \\
VL & $11 \pm 7.23^{\mathrm{a}}$ & $5 \pm 3.69^{\mathrm{a}}$ & $10 \pm 8.78^{\mathrm{a}}$ \\
\hline
\end{tabular}

Means followed of different letters in the same column differ between it self by Duncan's test $(\mathrm{P}<0.05)$. DM: dorsomedial quadrant; DL: dorsolateral quadrant; VM: ventromedial quadrants; VL: ventrolateral quadrant. Scrotum without bipartition (group I); Scrotum showing a ventral division until the middle of the testis (group II); and Scrotum separation extended beyond the middle of the testis (group III).

In bovines, the branch that supplies the head portion of the epididymis is denominated "cranial branch", and the one that supplies the body is called "caudal branch" of the epididymus (DYCE et al., 1997). There are no reports in the literature describing the level in which the lateral branch is originated from the medial testicular artery.

The fine network of the testicular veins in the pampiniform plexus evaluated by this study agrees with that described by different authors in bovines (HESS et al., 1990; MACHADO et al., 1996; CARVALHAL et al., 2000). The conical shape of the spermatic funiculus in the testis is similar to the description made by CARVALHAL et al. (2000) in ovines.

Cranial and caudal testicular arteries branches were observed in caprines (OLIVEIRA et al., 2002) and in buffalos (PASSIPIERI et al., 1998). Sinuous branches, originated from cranial and caudal arterial branches, are denominated testicular or collateral branches by RODRIGUES \& BORELLI (1990) and SOUZA et al. (1992), the same classification adopted in the present study.

Table 3 - Mean and respective standard deviations relative to the total amount of penetrating branches in caprines testicles with different scrotal division levels.

\begin{tabular}{lc}
\hline Groups & Penetrating branches \\
\hline I & $32 \pm 14.22^{\mathrm{a}}$ \\
II & $15 \pm 7.29^{\mathrm{b}}$ \\
III & $26 \pm 16.92^{\mathrm{a}}$ \\
\hline
\end{tabular}

Means followed of different letters in the same column differ between it self by Duncan's test $(P<0.05)$. Scrotum without bipartition (group I); Scrotum showing a ventral division until the middle of the testis (group II); and Scrotum separation extended beyond the middle of the testis (group III). 
In groups I and III, the total number of testicular penetrating branches in each particular quadrants differs from RODRIGUES \& BORELLI (1990) observations in ovine, where the most populated quadrant was the dorsomedial and the less populated was the ventrolateral in the right and left testicles. The most populated quadrants in the group II (dorsolateral and ventrolateral) differ from the study described by RODRIGUES \& BORELLI (1990) in ovine species. Among the group II, vascular casts showed that the ventromedial quadrant had less number of branches than the dorsomedial quadrant.

The similar number of penetrating branches among the right and left testicles were also observed in ovine by RODRIGUES \& BORELLI (1990); however, results that compare the testicular vascularization among the animals with different levels of scrotal division were not found in the literature.

In summary, macroscopic study showed that the origin, distribution and localization of the testicular arteries are similar to other domestic ruminants, and they do not show any differences related to the degree of scrotal division in caprines.

\section{ACKNOWLEDGEMENTS}

This study was supported by The National Council for Scientific and Technological Development (CNPq), $\mathrm{n}-$. 478080/03-4.

\section{REFERENCES}

BARONE, R. Trattato di anatomia comparata dei mammiferi domestici. Angiologia: cuore e arterie, Bologna: Edagricole, 2003. 5v.

CARVALHAL, R. et al. Estudo morfológico do funículo espermático em ovinos da raça Corriedale (Ovis aries, L. 1758). Brazilian Journal of Veterinary Research and Animal Sciense, São Paulo, v.37, n.1, p.348-354, 2000.
DYCE, K.M. et al. Tratado de anatomia veterinária. Rio de Janeiro: Guanabara, 1997. 1v.

GETTY, R. Sisson/Grossman anatomia dos animais domésticos. Rio de Janeiro: Interamericana, 1986. 2v.

HESS, H. et al. Vascular morphology of the bovine testis. Anatomischer Anzeiger, Helle, v.170, p.119-132, 1990.

MACHADO, M.R.F. et al. Contribution to the study of the funiculus spermaticus in murrah buffaloes (Bubalus bubalis LINNAEUS, 1978). Brazilian Journal Veterinary Research and Animal Science, São Paulo, v.13, n.1, p.713, 1996.

NOORDHUIZEN-STASSEN, E.N. et al. Functional arteriovenous anastomoses between the testicular artery and the pampiniform plexus in the spermatic cord of rams. Journal Reproduction and Fertility, Southamptam, v.75, p.193-201, 1985.

OLIVEIRA, R.R. et al. Aspectos morfométricos e irrigação arterial do escroto e testículo em caprinos nativos do estado de Pernambuco. Revista Brasileira de Reprodução Animal, Belo Horizonte, v.5, p.129-131, 2002.

PASCUALY, O.S.; ELOY, A.X. Evaluacion de parametros reproductivos en machos ovinos y caprinos en el CNPC. Sobral: IICA/EMBRAPA/CNPC, 1985. 22p. (Boletim Tecnico).

PASSIPIERI, M. et al. Contribuição ao estudo da vascularização arterial do testículo de búfalos da raça Murrah. Brazilian Journal Veterinary Research and Animal Science, São Paulo, v.35, p.24-66, 1998.

RODRIGUES, C.A., BORRELLI, V. Contribuição ao estudo da vascularização arterial do testículo em ovinos da raça Corriedale (Ovis aries Linnaeus, 1758). Brazilian Journal Veterinary Research and Animal Science, São Paulo, v.27, p.268-274, 1990.

SOUZA, M.R.Q. et al. Contribuição ao estudo da vascularização arterial do testículo em caprinos (Capra hircus - Linnaeus, 1758), da raça Bhuj Brasileira. Ars Veterinária, Porto Alegre, v.8, p.100-117, 1992. 